ORIGINAL ARTICLE

\title{
Inhibition of the Angiotensin I Converting \\ Enzyme (ACE) and proteolysis of non-fat probiotic yogurt
}

\section{Inibição da Enzima de Conversão da Angiotensina I (ECA) e proteólise do iogurte probiótico sem gordura}

\author{
Azizeh Rezaei ${ }^{1}$, Shabboo Amirdivani ${ }^{2 *}$ (1), Asghar Khosrowshahi Asl ${ }^{3}$, \\ Hassan Malekinejad ${ }^{4}$, Shahin Zomorodi ${ }^{5}$, Fatemeh Hosseinmardi ${ }^{6}$
}

${ }^{1}$ Azad University Sanandaj Branch, Faculty of Agriculture, Department of Food Science and Technology, Sanandaj Iran

${ }^{2}$ Shahid Beheshti University of Medical Sciences, Faculty of Nutrition Sciences and Food Technology/National Nutrition and Food Technology, Department of Food Technology, Tehran - Iran

${ }^{3}$ Urmia University, Faculty of Agriculture, Department of Food Science and Technology, Urmia - Iran

${ }^{4}$ Urmia University of Medical Science, Faculty of Pharmacy, Department of Pharmacology and Toxicology, Urmia Iran

${ }^{5}$ Agricultural Research Center of West Azerbaijan, Department of Engineering, Urmia - Iran

${ }^{6}$ Shahr-e-Qods Islamic Azad University, Department of Food Science and Technology, Tehran - Iran

*Corresponding Author: Shabboo Amirdivani, Shahid Beheshti University of Medical Sciences, Faculty of Nutrition Sciences and Food Technology/National Nutrition and Food Technology, Department of Food Technology, West Arghavan, Farahzadi Blvd, Saadat Abad, Tehran - Iran, e-mail: sh.mohajer1979@gmail.com

Cite as: Rezaei, A., Amirdivani, S., Asl, A. K., Malekinejad, H., Zomorodi, S., \& Hosseinmardi, F. (2019). Inhibition of the Angiotensin I Converting Enzyme (ACE) and proteolysis of non-fat probiotic yogurt. Brazilian Journal of Food Technology, 22, e2018234. https://doi.org/10.1590/1981-6723.23418

\begin{abstract}
Yogurt is an important source of many biologically active peptides with specific health benefits. The majority of the bioactive peptides produced during yogurt manufacture are related to angiotensin converting enzyme inhibitory (ACE-I) peptides. The present study evaluated the proteolysis and angiotensin converting enzyme (ACE) inhibitory activities of non-fat probiotic yogurt supplemented with sodium caseinate ( 0 to $4 \%$ ), and Mentha piperita (peppermint) extract ( 0 to $0.4 \%)$ during 20 days of storage. Good correlation $(R=0.90)$ was found between the growth of Lactobacillus casei LFTI ${ }^{\circledR}$ L26 and ACE inhibition in all samples during the initial stages of storage, as compared to the control yogurt, with a significant $(p<0.05)$ decrease after storage. The results showed that the addition of sodium caseinate and peppermint extract had a significant $(p<0.05)$ effect on proteolysis and the viability of $L$. casei $\mathrm{LFTI}^{\circledast} \mathrm{L} 26$, enhancing the ACE activity. The IC50 values of the sample containing $0.4 \%$ of peppermint and of the sample containing $4 \%$ of sodium caseinate were 0.12 and $0.02 \mathrm{mg} / \mathrm{mL}$ respectively. The results showed that the use of $4 \%$ of sodium caseinate and $0.4 \%$ of peppermint extract could provide higher probiotic viability $\left(1.3 \times 10^{7} \mathrm{cfu} / \mathrm{g}\right)$ on the 20 th day of storage.
\end{abstract}

Keywords: Probiotic; Sodium caseinate; Peppermint extract; Proteolysis; Angiotensin converting enzyme; Yogurt. 


\section{Resumo}

O iogurte é uma importante fonte de muitos peptídeos biologicamente ativos que podem apresentar benefícios específicos à saúde. A maioria dos peptídeos bioativos produzidos durante a produção de iogurte está relacionada aos peptídeos inibidores da enzima conversora da angiotensina (ECA-I). O presente estudo avaliou a proteólise e as atividades inibitórias da enzima conversora de angiotensina (ECA) de iogurte probiótico desnatado, suplementado com caseinato de sódio (0 a 4\%) e extrato de Mentha piperita ( 0 a 0,4\%), durante 20 dias de armazenamento. Foi encontrada uma boa correlação entre o crescimento de Lactobacillus casei LFTI ${ }^{\circledR}$ L2 e a inibição da ECA em todas as amostras $(R=0,90)$. Todos os iogurtes suplementados mostraram boa atividade inibitória da ECA durante os estágios iniciais de armazenamento em comparação com o iogurte controle, com significativa diminuição $(p<0,05)$ após o armazenamento. Os resultados mostraram que a adição de caseinato de sódio e extrato de Mentha piperita teve efeito significativo $(p<0,05)$ na proteólise e na viabilidade de $L$. casei LFTI ${ }^{\circledR}$ L26, aumentando a atividade da ECA. O valor de IC50 da amostra contendo 0,4\% de hortelã-pimenta e a amostra contendo $4 \%$ de caseinato de sódio foi de 0,12 e 0,02 $\mathrm{mg} / \mathrm{mL}$, respectivamente. Os resultados mostraram que a utilização de $4 \%$ de caseinato de sódio e 0,4\% de extrato de hortelã-pimenta poderia proporcionar maior viabilidade probiótica $\left(1,3 \times 10^{7} \mathrm{UFC} / \mathrm{g}\right)$ aos 20 dias de armazenamento.

Palavras-chave: Probiotic; Caseinato de sódio; Extrato de hortelã-pimenta; Proteólise; Enzima conversora de angiotensina; logurte.

\section{Introduction}

The prevalence of hypertension is a global concern, reaching about $40 \%$ of the worldwide adult population (Mendis et al., 2011) and 20.8\% of Brazilians (Selem et al., 2014). It increased dramatically in Brazil, by about tenfold, over the last four decades (Ruilope et al., 2018), such that it is now responsible for more than a third of all deaths in this country (Pimenta \& Assunção, 2015). These high rates have occurred despite the availability of advanced blood pressure control drugs, so it appears that lifestyle habits are mainly effective in this case (Selem et al., 2014; Ribeiro et al., 2018). Thus diet was identified as the single most important factor to prevent and control hypertension, which is easier for the public to interpret (Selem et al., 2014). Hence fermented milk products are becoming increasingly popular because of the numerous health benefits they provide, associated with highly digestible nutrients especially for those with lactose intolerance, and also large amounts of bioactive peptides (Amirdivani, 2015; Chen et al., 2015). Many peptides with bioactive characteristics have been isolated from different fermented dairy products, including fermented milk, cheese and yogurt. These peptides have many benefits in inhibiting diseases such as cancer and hypertension, and are already used in commercial products.

The inhibition of the angiotensin I-converting enzyme (ACE) is considered to be a useful therapeutic approach in the treatment of high blood pressure in both diabetic and non-diabetic patients (Omedi et al., 2016; Chen et al., 2015; Ibrahim et al., 2016). Most of the milk-derived peptides with multiple functions are involved in the production of bioactive substances (Smacchi \& Gobbetti, 2000; Rojas-Ronquillo et al., 2012). The in vitro ACE-I activity could be related to the liberation of the peptide due to casein degradation (Donkor et al., 2007) as a result of proteolysis by L. casei. On the other hand, with respect to the activity of the lactic acid bacteria, proteolysis is the most important biochemical process occurring in sour milk products during fermentation and storage (Wang et al., 2015, 2016), and improvements in the ACE inhibitory activity during fermentation depend on the degree of hydrolysis (Nejati et al., 2013). L. casei is known to be specific in the production of ACE inhibitors during fermentation. (Donkor et al., 2007; González-Olivares et al., 2014; Pihlanto et al., 2010). 
The study determined the ACE inhibitory activities of $L$. case $i$ as a commercial probiotic organism for the hydrolysis of sodium caseinate in yogurt. Lactic acid bacteria (LAB) are known to be probiotic organisms which are important for food fermentations (Wang et al., 2015; González-Olivares et al., 2014; Pihlanto et al., 2010). The incorporation of probiotic organisms such as $L$. casei in yogurt provides the potential to improve the quality of the product and of the consumer's health status. In addition, peppermint is one of the oldest medicinal plants, is rich in polyphenolic compounds and flavonoids, and is widely used in the people's diet. Recent studies have shown that phenolic compounds have high antioxidant activity and therapeutic properties, including the prevention of diabetes and hypertension. In addition, plants rich in flavonoids have ACE-I activities (Sweetie et al., 2007; Amirdivani \& Baba, 2011).

Thus this is a worthwhile issue to study, and by doing so, the ability to prevent high blood pressure could be greatly improved. However, the inhibitors present in food are not as powerful as the drugs used to treat high blood pressure, but they also have mild activities so it can be viewed as a natural functional food and placed in the daily diet.

\section{Material and methods}

\subsection{Materials}

Skim milk powder (SMP) was purchased from the Kaleh Dairy Company (Urmia, Iran). A DVS (Direct Vat Set) freeze-dried yogurt culture (YC-350: mixed cultures of L. delbrueckii subsp. Bulgaricus and S. thermophilus) was purchased from Chris Hansen, Denmark. L. casei LAFTI ${ }^{\circledR}$ L26 was obtained from DSM Food Specialties (Moorebank, NSW, Australia). Sodium caseinate with 78.95\% protein (Milad Khorasan, Iran), water and an alcoholic extract of peppermint (Zardband Iran) were also used. Freeze-dried rabbit lung angiotensin-converting enzyme, enalapril, O-phthaldialdehyde and the ACE substrate FAPGG (N-(3-(2-Furyl) acryloyl)-L-phenylalanyl-glycyl-glycine), were purchased from Sigma-Aldrich (St. Louis, MO, USA).

\subsection{Methods}

\subsubsection{Yogurt preparation}

Low-fat yogurt was prepared using skimmed milk (Kaleh, Urmia, Iran) standardized at 12,14 and $16 \mathrm{~g} / 100 \mathrm{~mL}$ total solids with skim milk powder and sodium caseinate ( 0 to $4 \%$ ). According to Table 1, sodium caseinate and peppermint extract were added to the pre-warmed $\left(41^{\circ} \mathrm{C}\right)$ non-fat milk and treated at $85^{\circ} \mathrm{C}$ for 15 minutes, followed by cooling. The DVS freeze-dried yogurt culture (YC-350: mixed cultures of L. delbrueckii subsp. Bulgaricus and S. thermophiles) was added at $1 \%(\mathrm{w} / \mathrm{v})$ and $L$. casei as the probiotic culture at $10 \mathrm{~g} / 100 \mathrm{~kg}$ of milk at a temperature of $\left(43 \pm 1{ }^{\circ} \mathrm{C}\right.$ ) (Shah \& Yogurt, 2003), and $250 \mathrm{~mL}$ aliquots of the mixture filled into disposable plastic containers. The plain yogurt was essentially prepared in the same manner. The yogurts were then incubated at $\left(43 \pm 1{ }^{\circ} \mathrm{C}\right)$ until the $\mathrm{pH}$ was reduced to 4.5 , followed by refrigeration $\left(5 \pm 1{ }^{\circ} \mathrm{C}\right)$ for up to 20 days. 
Table 1. Coded and real values for the independent variables used in the central composite design with three responses: sodium caseinate content $\left(\mathrm{X}_{1}\right)$, peppermint extract content $\left(\mathrm{X}_{2}\right)$, and storage time $\left(\mathrm{X}_{3}\right)$.

\begin{tabular}{|c|c|c|c|c|c|c|}
\hline \multirow[b]{2}{*}{ run } & \multicolumn{3}{|c|}{ Coded levels } & \multicolumn{3}{|c|}{ Real values } \\
\hline & $\begin{array}{c}\mathrm{X}_{1} \\
{[\% \mathrm{w} / \mathrm{w}]}\end{array}$ & $\begin{array}{c}X_{2} \\
{[\% v / v]}\end{array}$ & $\begin{array}{c}\mathrm{X}_{3} \\
\text { [day] }\end{array}$ & $\begin{array}{c}X_{1} \\
{[\% w / w]}\end{array}$ & $\begin{array}{c}X_{2} \\
{[\% v / v]}\end{array}$ & $\begin{array}{c}X_{3} \\
\text { [day] }\end{array}$ \\
\hline 1 & -1 & -1 & -1 & 0 & 0 & 4 \\
\hline 2 & +1 & +1 & +1 & 0 & 0 & 20 \\
\hline 3 & +1 & +1 & -1 & 0 & 0.4 & 4 \\
\hline 4 & +1 & +1 & +1 & 0 & 0.4 & 20 \\
\hline 5 & +1 & -1 & -1 & 4 & 0 & 4 \\
\hline 6 & +1 & -1 & +1 & 4 & 0 & 20 \\
\hline 7 & +1 & +1 & -1 & 4 & 0.4 & 4 \\
\hline 8 & +1 & +1 & +1 & 4 & 0.4 & 20 \\
\hline 9 & -1 & 0 & 0 & 0 & 0.2 & 12 \\
\hline 10 & +1 & 0 & 0 & 4 & 0.2 & 12 \\
\hline 11 & 0 & -1 & 0 & 2 & 0 & 12 \\
\hline 12 & 0 & +1 & 0 & 2 & 0.4 & 12 \\
\hline 13 & 0 & 0 & -1 & 2 & 0.2 & 4 \\
\hline 14 & 0 & 0 & +1 & 2 & 0.2 & 20 \\
\hline 15 & 0 & 0 & 0 & 2 & 0.2 & 12 \\
\hline 16 & 0 & 0 & 0 & 2 & 0.2 & 12 \\
\hline 17 & 0 & 0 & 0 & 2 & 0.2 & 12 \\
\hline 18 & 0 & 0 & 0 & 2 & 0.2 & 12 \\
\hline 19 & 0 & 0 & 0 & 2 & 0.2 & 12 \\
\hline 20 & 0 & 0 & 0 & 2 & 0.2 & 12 \\
\hline
\end{tabular}

\subsubsection{Determination of the $\mathrm{pH}$ value and TA (Titratable Acid)}

The $\mathrm{pH}$ value was determined after calibrating a digital $\mathrm{pH}$ meter using standard buffers at $\mathrm{pH}$ values of 4 and 7. The electrode of the $\mathrm{pH}$ meter was immersed directly in the yogurt samples and the $\mathrm{pH}$ recorded. The acidity was determined by titrating with $0.1 \mathrm{~mol} \mathrm{~L}^{-1} \mathrm{NaOH}$ in the presence of 2 drops of phenolphthalein indicator until the appearance of an amethystine color, according to the Official Methods of the Association of Official Analytical Chemists (1997). The acidity of the samples was calculated according to Equation 1.

Acidity $=\frac{V \times 10}{m}$

where $\mathrm{V}$ represents the volume of $\mathrm{NaOH}$ solution used and $\mathrm{m}$ the sample weight.

\subsubsection{Enumeration of the Viable Cell Count (VCC)}

The L. casei count was determined on MRS-agar (Amyl media, Dandenong, Australia) containing filter sterilized vancomycin in a final concentration of $0.35 \mathrm{~mol} \mathrm{~L}^{-1}$, which was added to the liquid after autoclaving the MRS-agar (DSM Co. catalogue). For the microbiological analyses, $5 \mathrm{~g}$ of a yogurt sample was suspended in $45 \mathrm{~mL}$ sterile peptone water $(0.1 \%)$ and serially diluted 10 -fold $\left(10^{3}\right.$ to $\left.10^{8}\right)$. Using the pour plate technique, $1 \mathrm{~mL}$ of each of the appropriate dilutions was cultured and the plates incubated at $37{ }^{\circ} \mathrm{C}$ for $72 \mathrm{~h}$ (Donkor et al., 2007). Plates showing 30-300 colonies were counted, and the results expressed as colony forming units per gram (cfu/g) of the sample.

\subsubsection{Proteolysis activity using the o-Phthaladehyde (OPA) reagent}

$0.15 \mathrm{~mL}$ of yogurt extract was added to $3 \mathrm{~mL}$ of OPA reagent (based on $\beta$-mercaptoethanol) (Papadimitriou et al., 2007; Nielsen et al., 2009) in a $5 \mathrm{~mL}$ quartz cuvette, mixed for 5 seconds, held for 2 minutes at room temperature, and the absorption at $340 \mathrm{~nm}$ read in a spectrometer (Beckman, America). The blank was prepared by substituting the yogurt sample with distilled water. The degree of proteolysis was 
expressed based on the peptides measured and absorption by free amino acids (Amirdivani \& Baba, 2011). The peptide concentration was assessed against a tryptone standard.

\subsubsection{Determination of ACE inhibition Activity}

The ACE-inhibition activity of the yogurt was determined following the protocol described by Pihlanto (Pihlanto et al., 2010). According to this method, $0.125 \mathrm{~mL}$ of FAPGG reagent were added to $0.125 \mathrm{~mL}$ of yogurt samples in the cuvette. The mixture was stirred thoroughly, incubated in a water bath at $37{ }^{\circ} \mathrm{C}$ for $15 \mathrm{~min}$ and rabbit lung extract $\left(0.3 \mathrm{~mL}\right.$ in $50 \mathrm{mmol} \mathrm{L}^{-1}$ Tris-HCl$)$ added. The absorption was measured at $340 \mathrm{~nm}$ and the plate then incubated at $37^{\circ} \mathrm{C}$ for $10 \mathrm{~min}$ before reading the final absorption. Enalapril was used as the standard. ACE inhibition was determined in duplicate and the inhibitory activity calculated (Amirdivani \& Baba, 2011) using Equations 2 and 3:

$$
\begin{aligned}
& \text { ACE inhibitory acrivity } \%=100-\left(\frac{\Delta A_{\text {sample }}}{\Delta a_{\text {control }}}\right) * 100 \\
& \Delta A_{\text {sample }}=A_{0}-A_{10}, \Delta A_{\text {control }}=A_{0}-A_{10}
\end{aligned}
$$

\subsection{Experimental design and statistical analysis}

A centred central composite design was used, the results submitted to an ANOVA using SAS (version 9.1, SAS Institute Inc.), and the graphs drawn using Matlab software (version 7.10.0449, The MathWorks Inc.). Response surface methodology (RSM) is a collection of mathematical and statistical techniques used to design experiments, modelling, and for investigating the effects of some factors on one or more dependent variables (Bitaraf et al., 2012). The independent variables here were sodium caseinate, peppermint extract and the storage time. Table 1 shows the real and coded values of the factors. Twenty yogurt samples were evaluated according to the design, with three variables and three levels for each variable. The data were fitted to the second-order polynomial according to Equation 4.

$$
Y=\beta_{0}+\sum_{i=1}^{3} \beta_{i} X_{i}+\sum_{I=1}^{3} \beta_{i j} X_{i}^{2}+\sum_{i=I j=i+1}^{2} \sum_{i j}^{3} X_{i} X_{j}
$$

where $\mathrm{Y}$ represented the predicted response; $\beta_{0}$ the constant term; $\beta_{\mathrm{i}}$ the linear coefficient; $\beta_{\mathrm{ii}}$ the squared coefficient and $\beta_{\mathrm{ij}}$ the interaction coefficient, the $\mathrm{X}$ being the independent coded variables.

\section{Results and discussion}

\subsection{Determination of $\mathrm{pH}$ and acidity}

According to Figure 1 the $\mathrm{pH}$ of the sample decreased from 4.2 to 3.5 and the acidity increased from 1 to 1.2 during the 20 days of storage. It seems that the presence of the Mentha piperita extract caused an increase in the metabolic activity of the yogurt bacteria (Amirdivani \& Baba, 2011) and provided more substrates for bacterial proteolysis and cell growth in the presence of phenolic compounds (Shori \& Baba, 2011). The number of free amino groups and peptides increased due to proteolysis of the milk protein by bacterial enzymes (Chen et al., 2015). However, by increasing the amount of sodium caseinate, the $\mathrm{pH}$ increased and the acidity decreased (Aziznia et al., 2008), probably due to consumption of the carbohydrates by the microorganisms and the production of more organic acids (Østlie et al., 2003), thereby reducing the acidity and proteolysis, and releasing calcium from the casein micelles. Consequently, elevated free $-\mathrm{Ca}^{2+}$ concentrations may be a factor in lowering the blood pressure. González-Olivares et al. (2014) and Nielsen et al. (2009) reported that ACE-I was $<50 \%$ in the $\mathrm{pH}$ range from 4.3 to 4.6 . At pH 6 the activity of the cell-envelope proteinases and amino peptidases increased, followed by a decrease at lower $\mathrm{pH}$ values 
(Pan et al., 2010). González-Olivares et al. (2014) reported that the $-\mathrm{Ca}^{2+}$ concentration was correlated with $\mathrm{pH}$ and the ACE inhibitory activity. L. casei showed the highest ACE-inhibitory activity at low $-\mathrm{Ca}^{2+}$ concentrations. The present results were similar to the results found by González-Olivares et al. (2014). The highest ACE inhibition activity was observed when the $\mathrm{pH}$ of the yogurt reached 4.1 on the $20^{\text {th }}$ day of storage.

It was observed that the amounts of free amino acids and peptides were lowered when LAB degraded the proteins, a process which is time dependent (Donkor et al., 2007). During fermentation, the microorganisms started using both the proteins and the organic acids (Ruiz et al., 2004; Donkor et al., 2007), causing an increase in $\mathrm{pH}$ and decrease in acidity (Jai, 1990; Amirdivani, 2015) throughout the storage period. The yogurt containing 4\% sodium caseinate had a strong buffering capacity, explaining why the yogurt supplemented with sodium caseinate showed a weaker capacity for post acidification during the storage time than the others.
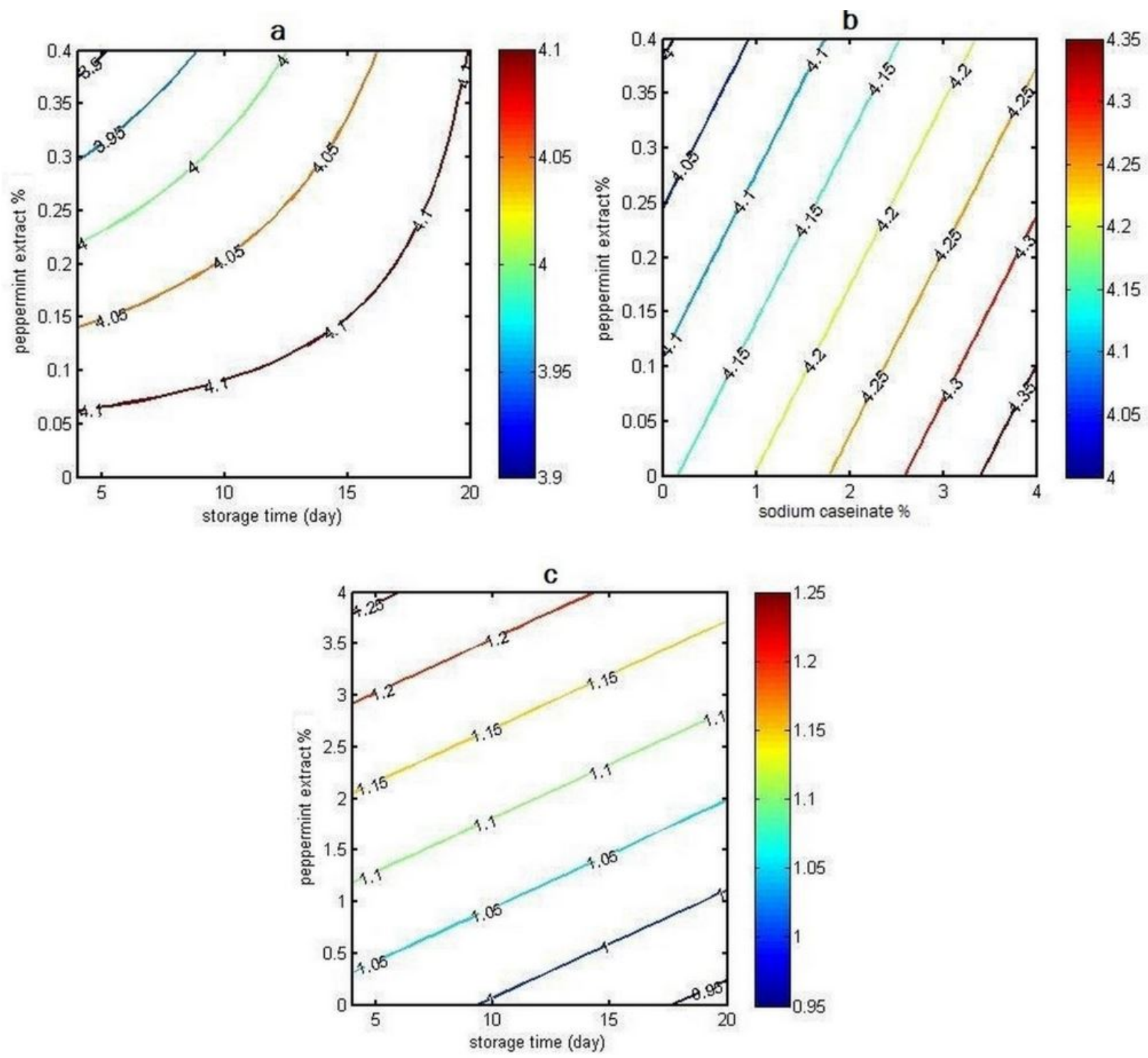

Figure 1. Response surface plot for $\mathrm{pH}$ as a function of (a) percent peppermint extract and storage time for a caseinate content of $2 \%$ and (b) percent peppermint extract and sodium caseinate content on the $12^{\text {th }}$ day of storage and (c) response surface plot for acidity as a function of percent peppermint extract and storage time for a sodium caseinate content of $2 \%$. 


\subsection{Probiotic cell count}

Figure 2 shows the change in the viable $L$. casei cell count. During the storage time, the number of $L$. casei cells first decreased and then increased. This study showed that the $\mathrm{pH}$ value decreased up to the $4^{\text {th }}$ day of storage, followed by an increase up to the $10^{\text {th }}$ day of storage. In addition, an increase in the amount of sodium caseinate added from 0 to $4 \%$ also increased the number of $L$. casei cells, which could be justified by increasing the amount of substrate available for bacterial growth (Pihlanto et al., 2010). Lactic acid bacteria need free amino acids for growth, more than natural milk proteins (Donkor et al., 2007) and therefore the LAB tend to use other proteins. Donkor et al. (2007) reported that proteolysis was dependent on time, and hence bacterial growth was slow in the early stages of fermentation and increased with time. The protein hydrolysis system is the most important factor for LAB survival, and thus the lack of free amino acids should have stimulated the culture to produce the free amino acids using its own proteolytic capability (Wang et al., 2015). Chen et al. (2015) reported a positive correlation between ACE-inhibition and free amino acids in a highly acid environment, which was associated with the bacterial activities. In the present study, the highest viable count was observed at $\mathrm{pH} 4.42$, parallel to the results found by Wang et al. (2015). Oligopeptides were produced by extracellular proteinases in the initial stages of casein hydrolysis during fermentation, but further hydrolysis of the oligopeptides is necessary in order to fulfil the needs of the culture. Amirdivani \& Baba (2011) reported that the survival of the starter bacteria was enhanced by increasing the amount of peppermint extract, but due to a lactose limitation for the starter bacteria applied in advance, there was a reduction in the number of $L$. casei cells with time, and therefore its growth was increased by using the sources and the synergistic influence of the starter culture (Samona \& Robinson, 2007). González-Olivares et al. (2014) reported that $L$. casei produced the most potent peptides with an $\mathrm{IC}_{50}$ value of $0.47 \mathrm{mg} / \mathrm{mL}$, after 48 hours fermentation. After fermentation, the yogurt containing sodium caseinate and peppermint extract had a $\mathrm{pH}$ value of 4.42 and a cell density of $9.1 \mathrm{log} \mathrm{cfu} / \mathrm{mg}$.
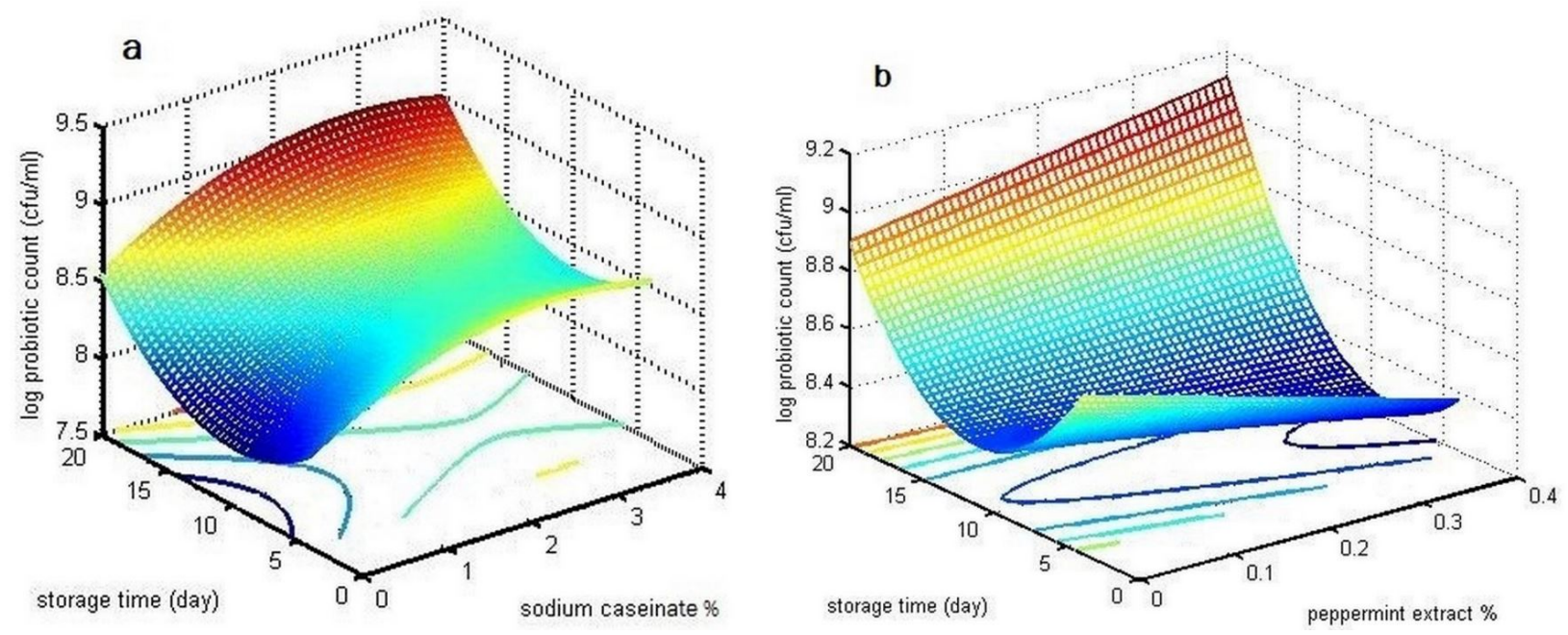

Figure 2. (a) Response surface plot for the probiotic count as a function of storage time (days) and sodium caseinate content, with a peppermint extract percentage of $0.2 \%$; (b) Response surface plot for the probiotic count as a function of storage time (days) and peppermint extract content, with a sodium caseinate percentage of $2 \%$.

\subsection{Evaluation of proteolysis}

Proteolysis is the most important biochemical process taking place during fermentation and storage (Amirdivani \& Baba, 2013). During fermentation, the milk proteins are hydrolyzed by the LAB exopeptidase, leading to an increase in the free $-\mathrm{NH}_{2}$ groups, which can be determined by the OPA method. According to Table 2 the statistical analyses suggested that the effects of sodium caseinate and storage time and the mutual effect of sodium caseinate and peppermint extract had significant effects on yogurt proteolysis $(p<0.05)$. 
According to Figure 3a, proteolysis increased during the storage time and with an increasing level of sodium caseinate. Figure $3 \mathrm{~b}$ shows that with a low amount of peppermint extract, proteolysis could be increased by increasing the sodium caseinate level, but with a large amount of this extract, an increase in the sodium caseinate level first increased proteolysis and then decreased it. One possible reason for this is that the extract leads to growth in the cell metabolism, consequently increasing the acidity (Ashraf \& Shah, 2011). Thus the lactic acid produced influenced the yogurt proteins, leading to protein denaturation and facilitating hydrolysis. However, due to hydrolysis, the peptides and free amino acids produced caused a decrease in the acidity. Similarly, by using up the sugar materials, the bacteria began to consume the organic acids and peptides produced and, as a result, proteolysis decreased (Frazier \& Westhoff, 1995). By increasing the amount of sodium caseinate, the growth of $L$. casei increased, due to provision of the requirements for growth, materials available and the production of intra and extracellular enzymes (Ashraf \& Shah, 2011; Frazier \& Westhoff, 1995). These enzymes can hydrolyse active biological peptides and bradykinin, the enzymes being widely used in the food industry. Proteolysis provides the necessary growth factors to enhance $L$. casei survival, in the form of peptides and amino acids, and thus proteolysis increases due to the materials available for growth.
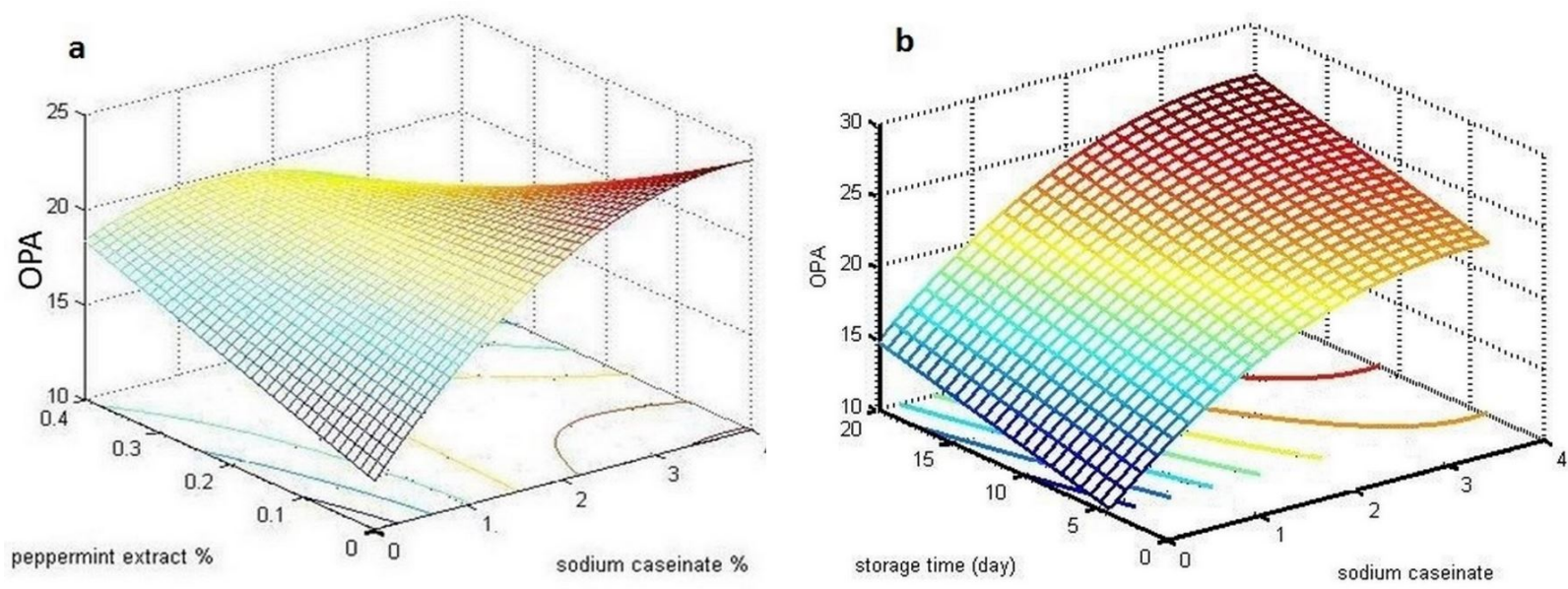

Figure 3. (a) The effect of sodium caseinate and peppermint extract on proteolysis; (b) The effect of sodium caseinate and storage time on proteolysis.

\subsection{ACE-inhibitory activity}

The ACE enzymatic activities can be transformed by the binding of biomolecules such as polyphenols, flavonoids and bioactive peptides onto the active binding sites of the enzyme (Donkor et al., 2007). The yogurt studied here contained peppermint extract, which is particularly rich in polyphenols and flavonoids (Sweetie et al., 2007), plus sodium caseinate as a source of bioactive peptides (Donkor et al., 2007). According to Figure 4a, the presence of a large amount of sodium caseinate provided plentiful substrate for $L$ casei growth, leading to an increase in ACE inhibition, although a decreasing trend was observed with a high level of peppermint extract (Figure $4 \mathrm{~b}$ ) after the first storage period, while showing a reversal of this trend on the $20^{\text {th }}$ day. Compared with similar results for the OPA values, the ACE Inhibitory activity was enhanced as proteolysis developed, although it decreased when proteolysis exceeded a certain level (Fung \& Liong, 2010) and by the $20^{\text {th }}$ day of storage the casein-derived bioactive peptides had been used up by the microorganisms. Thus the proteolytic activity of $L$. casei is associated with the production of bioactive compounds and with ACE inhibition (Donkor et al., 2007; Fung \& Liong, 2010).

These results showed that increasing levels of sodium caseinate and peppermint extract led to increases in bacterial growth. With respect to proteolytic activity, up to a certain level the amount of bioactive peptides and the rate of ACE inhibition increased significantly according to Table $2(p<0.05)$. However, as the 
bioactive peptides were used up by the microorganisms, so the rate of ACE inhibition was cut back. In the present study the $\mathrm{IC}_{50}$ values were from $0.035 \mathrm{mg} / \mathrm{mL}$ to $0.12 \mathrm{mg} / \mathrm{mL}$, which agrees with the results found in Leclerc et al. (2002). The highest $\mathrm{IC}_{50}$ value was observed in the yogurt supplemented with $4 \%$ peppermint extract $(0.12 \mathrm{mg} / \mathrm{mL})$.
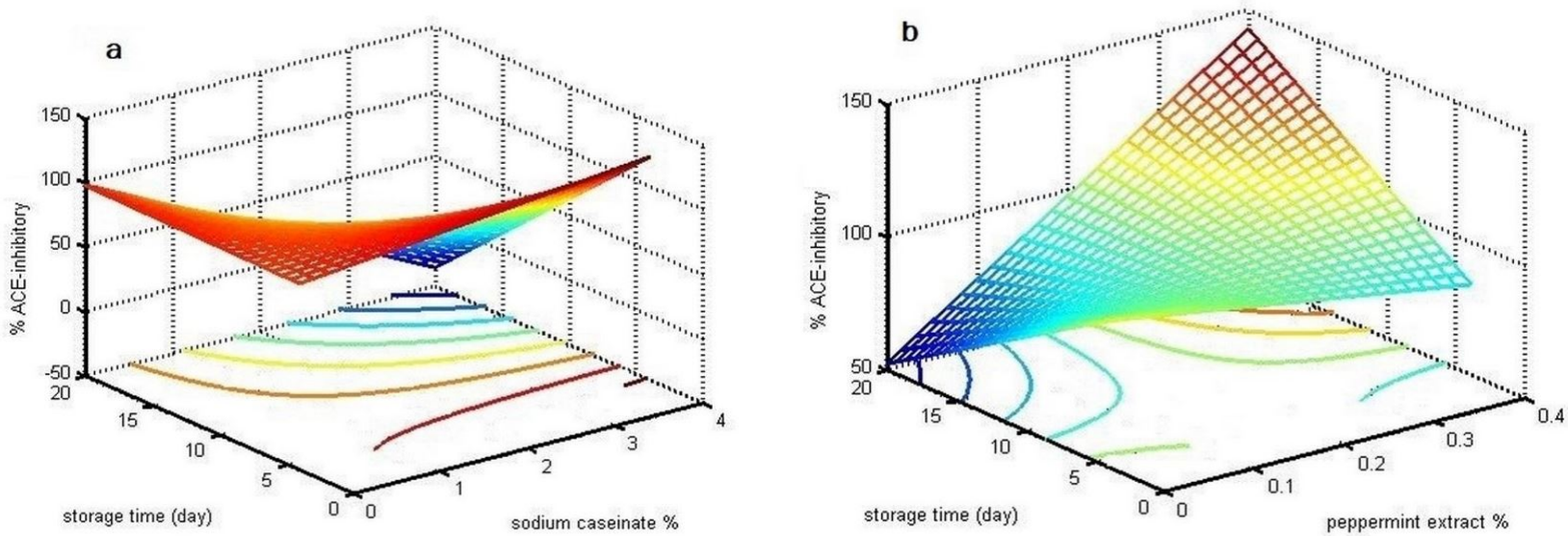

Figure 4. (a) Response surface plot for percent of ACE-inhibitory activity as a function of storage time (days) and sodium caseinate content, with a percent peppermint extract of $0.2 \%$; (b) Response surface plot for ACE-inhibitory activity as a function of storage time (days) and peppermint extract content with a sodium caseinate percent of $2 \%$.

Table 2. Analysis of variance for the responses of the dependent variables.

\begin{tabular}{|c|c|c|c|c|c|c|c|c|c|c|c|}
\hline \multirow{2}{*}{$\begin{array}{l}\text { Source of } \\
\text { variation }\end{array}$} & \multirow{2}{*}{ df } & \multicolumn{2}{|c|}{ pH } & \multicolumn{2}{|c|}{ Acidity } & \multicolumn{2}{|c|}{ Proteolysis } & \multicolumn{2}{|c|}{$\begin{array}{c}\text { Log probiotic } \\
\text { count }\end{array}$} & \multicolumn{2}{|c|}{$\begin{array}{c}\text { ACE-inhibitory } \\
\text { activity }\end{array}$} \\
\hline & & $\begin{array}{c}\text { Mean } \\
\text { square }\end{array}$ & F value & $\begin{array}{l}\text { Mean } \\
\text { square }\end{array}$ & F value & $\begin{array}{l}\text { Mean } \\
\text { square }\end{array}$ & F value & $\begin{array}{l}\text { Mean } \\
\text { square }\end{array}$ & F value & $\begin{array}{l}\text { Mean } \\
\text { square }\end{array}$ & F value \\
\hline Regression & 9 & 0.034579 & $6.013^{*}$ & 0.0273 & $6.0495^{* *}$ & 351.118 & $7.2044^{* *}$ & 0.207 & $6.2885^{* *}$ & 5.324 .606 & $9.6273^{* * *}$ \\
\hline Linear & 3 & 0.074049 & $12.876^{* * *}$ & 0.0553 & $12.249^{* * *}$ & 311.020 & $41.244^{* *}$ & 0.342 & $10.396^{* *}$ & 8410.47 & $15.206^{* * *}$ \\
\hline Square & 3 & 0.015295 & 26.595 & 0.0068 & 1.519 & 279.308 & $7.176^{*}$ & 0.187 & $5.687^{*}$ & 1.079 .964 & 19.526 \\
\hline Interaction & 3 & 0.014395 & 2.503 & 0.0197 & $4.38^{*}$ & 463.026 & $1.013^{* * *}$ & 0.0915 & 2.873 & 6.483 .385 & $11.72252^{* *}$ \\
\hline Lack of fit & 5 & 0.001195 & 0.1159 & 0.007 & 3.659 & 12.474 & 3.541 & 0.05 & 3.184 & 906.888 & 45.514 \\
\hline Pure error & 5 & 0.010307 & & 0.0019 & & 84.997 & & 0.0157 & & 1.992 .533 & \\
\hline Total & 19 & & & & & & & & & & \\
\hline $\mathrm{R}^{2}$ & & & 0.844 & & 0.845 & & 86.64 & & 0.85 & & 0.8965 \\
\hline$R^{2}$ (adj) & & & 0.703 & & 0.705 & & 74.61 & & 0.715 & & 0.8034 \\
\hline
\end{tabular}

*Significant at $p \leq 0.05 . * *$ significant at $p \leq 0.01 . * * *$ significant at $p \leq 0.001$ level.

\section{Conclusion}

The proteolytic activity of $L$. casei in the supplemented yogurt could have given rise to ACE inhibitory activity. While extensive research has centred on the bioactive peptides resulting from the addition of sodium caseinate or Mentha piperita extract separately, this study was carried out using them both together. To our knowledge, this is the first report on the use of probiotic yogurt containing sodium caseinate and Mentha piperita extract with an in vitro antihypertensive effect. Yogurt is a great alternative which can be included in the diet and is thus suitable for those with high blood pressure. The effects of other plant extracts necessitate further studies to develop a novel antihypertensive supplement. The present results showed that traditional products containing probiotics and bioactive compounds may possess multifunctional health benefits, but nevertheless, further research is needed to indicate these properties via in vivo and clinical studies. 


\section{Acknowledgements}

The authors are grateful to Prof. Khalil Farhadi, Prof. Minervini and Fatemeh Nejati, the Engineering and Agricultural Research Centre of West Azerbaijan and the Pharmacology and Toxicology Division of Urmia University, for their support during this study. This research was sponsored by the University of Urmia.

\section{References}

Amirdivani, S. (2015). Inclusion of Allium sativum in yogurt and its effects on inhibition of diabetes and hypertension: Associated by enzyme in vitro. Applied Food Biotechnology, 2(4), 237-247. http://dx.doi.org/10.22037/afb.v2i3.7714

Amirdivani, S., \& Baba, A. S. (2011). Changes in yogurt fermentation characteristics, and antioxidant potential and in vitro inhibition of angiotensin-1 converting enzyme upon the inclusion of peppermint, dill and basil. Lebensmittel-Wissenschaft + Technologie, 44(6), 1458-1464. http://dx.doi.org/10.1016/j.Iwt.2011.01.019

Amirdivani, S., \& Baba, A. S. (2013). Rheological properties and sensory characteristics of green tea yogurt during storage. Life Science Journal, 10(12), 378-390. http://dx.doi.org/10.7537/marslsj1012s13.66

Ashraf, R., \& Shah, N. P. (2011). Selective and differential enumeration of Lactobacillus delbrueckii subsp. bulgaricus, Streptococcus thermpohilus, Lactobacillus acidophilus, Lactobacillus casei and Bifidobacterium spp. in yoghurt: A review. International Journal of Food Microbiology, 149(3), 194-208. PMid:21807435. http://dx.doi.org/10.1016/j.ijfoodmicro.2011.07.008 Association of Official Analytical Chemists - AOAC. (1997). Official methods for analysis (16th ed.). Arlington: AOAC.

Aziznia, S., Khosrowshahi, A., Madadlou, A., \& Rahimi, J. (2008). Whey proteins concentrate and gum tragacanth as fat replacers in nonfat yogurt: Chemical, physical and microstructural properties. Journal of Dairy Science, 91(7), 2545-2552. PMid:18565911. http://dx.doi.org/10.3168/jds.2007-0875

Bitaraf, M. S., Khodaiyan, F., Mohammadifar, M. A., \& Mousavi, S. M. (2012). Application of response surface methodology to improve yogurt containing Lactobacillus reuteri. Food and Bioprocess Technology, 5(4), 1394-1401. http://dx.doi.org/10.1007/s11947-010-0433-2

Chen, Y., Li, C., Xue, J., Kwok, L., Yang, J., Zhang, H., \& Menghe, B. (2015). Characterization of angiotensin-converting enzyme inhibitory activity of fermented milk produced by Lactobacillus helveticus. Journal of Dairy Science, 98(8), 5113-5124 PMid:26004829. http://dx.doi.org/10.3168/jds.2015-9382

Donkor, O., Henriksson, A., Singh, T. K., Vasiljevic, T., \& Shah, N. P. (2007). ACE-inhibitory activity of probiotic yoghurt. International Dairy Journal, 17(11), 1321-1331. http://dx.doi.org/10.1016/j.idairyj.2007.02.009

Frazier, W. C., \& Westhoff, D. C. (1995). Food microbiology (4th ed.). Cary: Tata McGraw Hill Publisging Company.

Fung, W., \& Liong, M.-T. (2010). Evaluation of proteolytic and ACE-inhibitory activity of Lactobacillus acidophilus in soy whey growth medium via response surface methodology. Lebensmittel-Wissenschaft + Technologie, 43(3), 563-567. http://dx.doi.org/10.1016/j.Iwt.2009.10.004

González-Olivares, L. G., Añorve-Morga, J., Castañeda-Ovando, A., Contreras-López, E., \& Jaimez-Ordaz, J. (2014). Peptide separation of commercial fermented milk during refrigerated storage. Food Science and Technology, 34(4), 674-679. http://dx.doi.org/10.1590/1678-457X.6415

Ibrahim, S., Jiroutek, M. R., Holland, M. A., \& Sutton, B. S. (2016). Utilization of angiotensin converting enzyme inhibitors (ACEI) and angiotensin receptor blockers (ARB) in patients diagnosed with diabetes: Analysis from the National Ambulatory Medical Care Survey. Preventive Medicine Reports, 3(3), 166-170. PMid:27419010. http://dx.doi.org/10.1016/j.pmedr.2016.01.005

Jai, J. M. (1990). Modern food microbiology. New York: Chapman and Hall.

Leclerc, P.-L., Gauthier, S. F., Bachelard, H., Santure, M., \& Roy, D. (2002). Anthihypertensive activity of caseun-enreached milk fermented by Lactobacillus helveticus. International Dairy Journal, 12(12), 995-1000. http://dx.doi.org/10.1016/S09586946(02)00125-5

Mendis, S., Puska, P., \& Norrving, B. (2011). Global atlas on cardiovascular disease prevention and control. Geneva: WHO.

Nejati, F., Rizzello, C. G., Di Cagno, R., Sheikh-Zeinoddin, M., Diviccaro, A., Minervini, F., \& Gobbetti, M. (2013). Manufacture of a functional fermented milk enriched of Angiotensin-I Converting Enzyme (ACE)-inhibitory peptides and -amino butyric acid (GABA). Lebensmittel-Wissenschaft + Technologie, 51(1), 183-189. http://dx.doi.org/10.1016/j.lwt.2012.09.017

Nielsen, M., Martinussen, T., Flambard, B., Sørensen, K. I., \& Otte, J. (2009). Peptide profiles and angiotensin-I-converting enzyme inhibitory activity of fermented milk products: Effect of bacterial strain, fermentation $\mathrm{pH}$, and storage time. International Dairy Journal, 19(3), 155-165. http://dx.doi.org/10.1016/j.idairyj.2008.10.003

Omedi, J., Huang, W., Su, X., Liu, R., Tang, X., Xu, Y., \& Rayas-Duarte, P. (2016). Effect of five lactic acid bacteria starter type on angiotensin-I converting enzyme inhibitory activity and emulsifying properties of soy flour sourdoughs with and without wheat bran supplementation. Journal of Cereal Science, 69, 57-63. http://dx.doi.org/10.1016/j.jcs.2016.02.008

Østlie, H. M., Treimo, J., \& Narvhus, J. A. (2003). Effect of temperature on growth and metabolism of probiotic bacteria in milk. International Dairy Journal, 15(10), 989-997. http://dx.doi.org/10.1016/j.idairyj.2004.08.015

Pan, D., Luo, Y., \& Tanokura, M. (2010). Antihypertensive peptides from skim milk hydroiysate digested by cell-free extract of lactobacillus helveticus JCM1004. Food Chemistry, 91(1), 123-129. http://dx.doi.org/10.1016/j.foodchem.2004.05.055 
Papadimitriou, C., Vafopouloumastrojiannaki, A., Silva, S., Gomes, A., Malcata, F., \& Alichanidis, E. (2007). Identification of peptides in traditional and probiotic sheep milk yoghurt with angiotensin I-converting enzyme (ACE)-inhibitory activity. Food Chemistry, 105(2), 647-656. http://dx.doi.org/10.1016/j.foodchem.2007.04.028

Pihlanto, A., Virtanen, T., \& Korhonen, H. (2010). Angiotensin-I-converting enzyme (ACE) inhibitory activity and antihypertensive effect of fermented milk. International Dairy Journal, 20(1), 3-10. http://dx.doi.org/10.1016/j.idairyj.2009.07.003

Pimenta, A., \& Assunção, A. Á. (2015). Thermal discomfort and hypertension in bus drivers and chargers in the metropolitan region of Belo Horizonte, Brazil. Applied Ergonomics, 47, 236-241. PMid:25479993.

http://dx.doi.org/10.1016/j.apergo.2014.10.011

Ribeiro, Í. J. S., Cardoso, J. P., Freire, I. V., Carvalho, M. F., \& Pereira, R. (2018). Determinants of stroke in Brazil: A crosssectional multivariate approach from the National Health Survey. Journal of Stroke and Cerebrovascular Diseases, 27(6), 16161623. PMid:29454566. http://dx.doi.org/10.1016/j.jstrokecerebrovasdis.2018.01.013

Rojas-Ronquillo, R., Cruz-Guerrero, A., Flores-Nájera, A., Rodríguez-Serrano, G., Gómez-Ruiz, L., Reyes-Grajeda, J. P., Jiménez-Guzmán, J., \& García-Garibay, M. (2012). Antithrombotic and angiotensin-converting enzyme inhibitory properties of peptides released from bovine casein by Lactobacillus casei shirota. International Dairy Journal, 26(2), 147-154. http://dx.doi.org/10.1016/j.idairyj.2012.05.002

Ruilope, L., Nunes Filho, A. C. B., Nadruz Junior, W., Rodríguez Rosales, F. F., \& Verdejo-Paris, J. (2018). Obesity and hypertension in Latin America: current perspectives. Hipertensión y Riesgo Vascular, 35(2), 70-76. PMid:29361428. http://dx.doi.org/10.1016/j.hipert.2017.12.004

Ruiz, J. Á. G., Ramos, M., \& Recio, I. (2004). Angiotensin converting enzyme- inhibitory activity of peptides isolated from Manchego cheese. Stability under simulated gastrointestinal digestion. International Dairy Journal, 14(12), 1075-1080. http://dx.doi.org/10.1016/j.idairyj.2004.04.007

Samona, A., \& Robinson, R. (2007). K. Effect of yogurt cultures on the survival of bifidobacteria in fermented milks. Society of Dairy Technology, 47(2), 58-60. http://dx.doi.org/10.1111/j.1471-0307.1994.tb01273.x

Selem, C., Castro, M. A., César, C. L., Marchioni, D. M., \& Fisberg, R. M. (2014). Associations between dietary patterns and self-reported hypertension among brazilian adults: A cross-sectional population-based study. Journal of the Academy of Nutrition and Dietetics, 114(8), 1216-1222. PMid:24637242. http://dx.doi.org/10.1016/j.jand.2014.01.007

Shah, N., \& Yogurt, P. (2003). The product and its manufacture. In B. Caballero (Ed.), Encyclopedia of food science and nutrition. Cary: Academic Press. http://dx.doi.org/10.1016/B0-12-227055-X/01305-5.

Shori, A., \& Baba, A. S. (2011). Anioxidant activity and inhibition of key enzymes linked to type-2 diabetes and hypertension by Azadirachta indica-yogurt. Journal of Saudi Chemical Society, 17(3), 295-301. http://dx.doi.org/10.1016/j.jscs.2011.04.006

Smacchi, E., \& Gobbetti, M. (2000). Bioactive peptides in dairy products: syntesis and interaction with proteolytic enzyme. Food Microbiology, 17(2), 129-141. http://dx.doi.org/10.1006/fmic.1999.0302

Sweetie, R. K., Chander, R., \& Sharma, A. (2007). Antioxidant potential of mint (Mentha spicata L.) in radiation-processed lamb meat. Food Chemistry, 100(2), 452-458.

Wang, J., Li, C., Xue, J., Yang, J., Zhang, Q., Zhang, H., \& Chen, Y. (2015). Fermentation characteristics and angiotensin Iconverting enzyme-inhibitory activity of Lactobacillus helveticus isolate H9 in cow milk, soy milk, and mare milk. Journal of Dairy Science, 98(6), 3655-3664. PMid:25892687. http://dx.doi.org/10.3168/jds.2015-9336

Wang, P., Huang, R., Lu, S., Xia, W., Cai, R., Sun, H., \& Wang, S. (2016). RAGE and AGEs in mild cognitive impairment of diabetic patients: A cross-sectional study. PLoS One, 11(1), e0145521. PMid:26745632.

http://dx.doi.org/10.1371/journal.pone.0145521

Funding: The work has received funding from Urmia University. 